\title{
An Approach Based on TRIZ Methodology and SERVQUAL Scale to Improve the Quality of Health-Care Service: A Case Study
}

\author{
Sağlık Hizmetinin Kalitesini Arttırmak için TRIZ Metodolojisi ile SERVQUAL Skalasına \\ Dayanan Bir Yaklaşım: Bir Uygulama
}

\author{
Serkan ALTUNTAŞ', Engin YENER ${ }^{2}$
}

\begin{abstract}
A new innovative approach based on theory of inventive problem solving (TRIZ) and the quality service measurement scale (SERVQUAL) is proposed to improve the quality of health-care service. TRIZ is used at a wide range of area in industrialized countries to solve problems, while SERVQUAL is used very extensively to measure quality of service sector (especially in health-care service) by many researchers. Su et al. (2008) proposed a systematic framework based on TRIZ to solve the service quality problems. The aim of this study is to develop a methodology to improve the quality of health-care service sector by adapting the SERVQUAL scale parameters to TRIZ in the light of the study by Su et al. (2008). Firstly, we mapped the determinants of SERVQUAL scale with the analogical explanations of the 39 TRIZ engineering parameters. Then, questionnaire was prepared for confirming our study. Questionnaire was applied to ten doctors (three of them are Professors (academic) and the rest of them are regular doctors) at the Atatürk University Hospital in Turkey. Finally, a case study was conducted to show how to apply this new innovative approach. Application area of TRIZ is extended thanks to this study.
\end{abstract}

Keywords: TRIZ, SERVQUAL, hospital, service quality, healthcare service quality.

\section{INTRODUCTION}

Quality can be considered as very significant element to make a difference in the strong competition environment for companies. Solution approaches are very important for organizations to obtain sufficient quality level. Innovative approach is necessary to obtain sufficient quality level and to be successful as an organization due to the selective customers. At this point, Theory of Inventive Problem Solving (TRIZ) is given a systematic way to find innovative solutions for researches, engineers, employees and decision makers. Although translation of TRIZ in English is the "theory of inventive problem solving", it comes from the Russian phrase teorija rezhenija izobretatelskih

\section{ÖZET}

Sağlık hizmetlerinin kalitesini arttırmak için yaratıcı problem çözme teorisi (TRIZ) ve hizmet kalitesi ölçüm skalasına (SERVQUAL) dayanan yeni bir yenilikçi yaklaşım önerilmiştir. SERVQUAL servis kalitesinin ölçümü için (özellikle sağlık hizmetlerinde) yaygın şekilde kullanılırken, TRIZ, sanayileşmiş ülkelerde sorunların çözümü için geniş bir alanda kullanılmaktadır. Su et al. (2008), servis kalitesi ile ilgili problemlerin çözümü için TRIZ'e dayanan sistematik bir çerçeve önermiş̧ir. Bu çalışmada ise, SERVQUAL skalasının parametrelerini TRIZ'e adapte ederek, sağlık hizmetleri sektörünün kalitesini arttırmak için Su et al. (2008)'ün çalışması ışığında bir metodoloji önerilmektedir. Illk olarak TRIZ'in 39 mühendislik parametresinin SERVQUAL skalası ile benzeşen boyutları eşleştirilmiştir. Sonra çalışmamızı doğrulamak için anket formu hazırlanmıştır. Anket formumuz, Türkiye'de, Atatürk Üniversitesi Hastanesindeki on doktora(3'ü profesör diğerleri uzman doktor) uygulanmıştır. Son olarak, bu yeni yenilikçi yaklaşımın nasıl uygulanacağını göstermek için bir örnek uygulama yürütülmüştür. TRIZ'in uygulama alanı bu çalışma sayesinde genişletilmiştir.

Anahtar Kelimeler: TRIZ, SERVQUAL, hastane, servis kalitesi, sağlık hizmetleri kalitesi.

zadach (Rantanen and Domb, 2008). "Altshuller, the proponent of the TRIZ method, was analyzed thousands of worldwide patents from leading engineering fields, and categorized these patents in a novel way by removing the subject matter to identify the problem-solving processes instead of classifying the patents by industry" (Su et al., 2008). He began developing TRIZ in 1946, but it was not until 1956 that his first paper on TRIZ (written with his friend Rafael B. Shapiro) was published (Savransky, 2000). The development of the first navigators in TRIZ was done by examining several thousand inventions and there are now more than 2.5 million of investigated inventions (Orloff, 2006). Orloff (2006) also indicates that TRIZ is the only constructive theory of invention

${ }^{1}$ Corresponding Author, Res. Ass., Bayburt University, Faculty of Engineering, Department of Industrial Engineering, saltuntas@bayburt.edu.tr

${ }^{2}$ Assist. Prof., Bayburt University, Faculty of Engineering, Department of Civil Engineering, eyener@bayburt.edu.tr 
and, based on its essence, of engineering creativity at the beginning of the 21st century. TRIZ is applied in many technical and nontechnical fields such as marketing, education, management, manufacturing (Rantanen and Domb, 2008). It is also proved a systematic way for ones who want to solve their problem with innovative approach. TRIZ gives quick and effective solution(s) compared to other methods when the solution of the problem is not found by known methods, namely mathematical methods, simulation e.tc. Sener (2006) compared TRIZ method with other innovative methods, namely six sigma, brain storming, Sinektik, Taghuci and Quality function deployment (QFD). Domb (2003) discussed TRIZ for non technical problem solving. Details on TRIZ can also be found in (Savransky, 2000; Orloff, 2006; Silverstein et.al., 2008).

There are many constrains while solving real life problems. These constrains prevent to obtain our aim that we want to achieve. Some constrains may contradict to each other. If there are at least two variables which contradict to each other in the problem, we can use TRIZ methodology to solve problem. Altshuller has defined a matrix which was called contradiction matrix. This matrix has 39X39 dimensions. There are 39 technical parameters which causes contradiction. These are called "39 standard engineering parameters". The title line and the title column of the contradiction matrix show the worsening and the improving features, respectively. 40 innovative principles have defined for the solution of conflicts. The cell of the intersection of columns and lines includes appropriate solutions in the contradiction matrix. Finally, fundamental solution of TRIZ environment has been created by typing the innovative principles in the intersections of the cell columns and the lines. The first 5 feature for contradiction matrix is shown in Table 1. As can be seen from this table, there are two features for parameters, namely improving and worsening. If we select weight of stationary (2) for improving features and length of stationary (4) for worsening feature, next the inventive principles No. 10 ('Prior Action'), No. 1('Segmentation'), No. 29 ('Use pneumatic or hydraulic systems'), and No. 35 ('Transforming physical or chemical states') might be the applicable suggestions.

SERVQUAL scale is employed very extensively for measuring the quality of service systems. This scale is based on the basis of 10 parameters. These are: Access, Competence, Communication, Courtesy, Credibility, Reliability, Responsiveness, Security, Understanding the Customer and Tangibles. Details on researches related to service quality improvement in hospitals with SERVQUAL scale can be found in (Babakus and Mangold, 1992; Vandamme and Leunis, 1993; Lam, 1997; Lee, 2005; Çaha, 2007; Zaim et.al., 2009). Details on SERVQUAL scale for examples of theoretical knowledge and practical applications and measuring service quality can be also found in (Gronroos (1984); Parasuraman et.al. (1985); Parasuraman et.al. (1988); James (1990); Parasuraman et.al. (1991); Parasuraman et.al. (1994); Elizabeth (1995); Tony and Stephen (1997)). Furthermore, details on SERVQUAL scale can be found in review studies: Buttle, 1996; Asubonteng et.al., 1996; Coulthard, 2004; Ladhari, 2008; Ladhari, 2009; Gilmore and McMullan, 2009.

Especially, TRIZ has been developed for solution of the problem related to the production systems. However, in the last period, a new TRIZ based methodology is proposed to service sector to improve service quality (Su and Lin, 2008; Su et al., 2008). Cool (2005) presented a methodology for marketing/selling TRIZ. Jiang et.al.(2011) developed a conceptual framework of service system design by using TRIZ. Retseptor (2003) gave some examples

Table 1: The First 5 Feature for Contradiction Matrix with Suggested Inventive Principles.

\begin{tabular}{|c|c|c|c|c|c|c|}
\hline & & \multicolumn{5}{|c|}{ Worsening Feature } \\
\hline & & $\begin{array}{l}\text { 1: Weight } \\
\text { of Moving } \\
\text { Object }\end{array}$ & $\begin{array}{l}\text { 2: Weight } \\
\text { of } \\
\text { Stationary }\end{array}$ & $\begin{array}{l}\text { 3: Length } \\
\text { of } \text { Moving } \\
\text { Object }\end{array}$ & $\begin{array}{l}\text { 4: Length } \\
\text { of } \\
\text { Stationary }\end{array}$ & $\begin{array}{l}\text { 5: Area of } \\
\text { Moving } \\
\text { Object }\end{array}$ \\
\hline \multirow{5}{*}{ 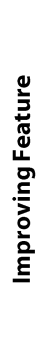 } & 1: Weight of Moving Object & - & - & $\begin{array}{l}15,8 \\
29,34\end{array}$ & - & $\begin{array}{l}29,17 \\
38,34\end{array}$ \\
\hline & 2: Weight of Stationary & - & - & - & $\begin{array}{r}10,1 \\
29,35\end{array}$ & - \\
\hline & 3: Length of Moving Object & $\begin{array}{l}8,15 \\
29,34\end{array}$ & - & - & - & $\begin{array}{c}15,17 \\
4\end{array}$ \\
\hline & 4: Length of Stationary & - & $\begin{array}{l}35,28 \\
40,29\end{array}$ & - & - & - \\
\hline & 5: Area of Moving Object & $\begin{array}{l}2,17 \\
29,4\end{array}$ & - & $\begin{array}{c}14,15 \\
18,4\end{array}$ & - & - \\
\hline
\end{tabular}


related to application of the 40 Principles on Quality Management area. Zhang et al. (2005) proposed a TRIZ based methodology service design. Shirwaiker R.A. and Okudan G.E. (2008) reviewed the applications of TRIZ and axiomatic design for manufacturing and designing problems. Akay et al. (2008) evaluated TRIZ methodology for the human factors. Movarrei and Vessal (2006) applied TRIZ to customer relationship management. Shahin and Pourhamidi (2011) proposed a new generic contradiction matrix (39 traditional parameters changed to 12 major parameters) for service sector. They conduct a case study in a hotel. Lin and Su (2007) used TRIZ methodology for creating new services. Chen et.al. (2010) developed a systematic service system innovation model based on TRIZ method for the improvement of the aging in place and conducted a survey study by asking six experts. In addition to the mentioned studies above, there are some studies which applied TRIZ methodology in many social fields, such as service operations management (Zhang, et.al., 2003), education (Marsh, et.al., 2004), finance (Dourson, 2004), marketing, sales and advertising (Retseptor, 2005), supply chain management (Movarrei and Vessal, 2007), human capital (Ersin, 2009), education standards (Cemgil, 2006), crowd management (Pin et.al.,2011) and marketing management (Zouaoua, et.al., 2010). Recently, combining TRIZ methodology with other methods is popular (Su and Lin, 2008). Details on the combination of the TRIZ with other methods are given in (Petrali, (2004); Hipple, (2005a); llevbare et.al.(2011)). Wang and Chen (2010) combined lean six sigma methodology and TRIZ method to improve banking service. Hipple (2005b) empasized the integration and strategic use of TRIZ with the CPS process. Sakao (2007) combined three tools: LCA (life cycle assessment), QFDE (quality function deployment for environment), and TRIZ for designning of products. Tong et al. (2006) proposed an automatic patent classification for TRIZ users. Bariani (2004) presented the design for manufacture and assembly (DFMA) method and TRIZ based approach for part count reduction. Wei et al. (2006) combined TRIZ and the fuzzy analytical hierarchy process (AHP) for the automated manufacturing systems. Chai et al. (2005) demonstrated the viability of applying TRIZ to services. Tsai et al. (2004) designed a new metal seat mechanism for the ball valve by using the Quality Function Deployment (QFD) technique and TRIZ method. Yamashına et al. (2002) proposed Innovative Product Development Process (IPDP) by combining QFD with TRIZ for enabling the creation of new products.
Medicine is one of non-technical area which TRIZ applications is used (Zlotin et al. 2005). In this paper, a new innovative approach is proposed to improve service quality in hospital. This new approach is based on TRIZ, which is used in a wide area in industrialized countries, and SERVQUAL, which is used by many researchers to measure service quality in hospital. Application area of TRIZ is extended thanks to this study.

A general outline of the paper is as followed. TRIZ methodology which proposed by Su et.al. (2008) is given to introduce it briefly. Then, we introduce that SERVQUAL scale is adapted to TRIZ using the methodology by Su et al. (2008). Then, a case study is given. Finally, the conclusion and future research directions are given.

\section{PROPOSED TRIZ METHODOLOGY BY SU ET.AL. (2008)}

Su et.al. (2008) showed TRIZ application in the service industry. Their TRIZ methodology comprises of eight main stages confirming to the general TRIZ algorithm. The stages are;

Stage 1: Define the scope of the problem and identify the service sector under which it is classified

Stage 2: Extract the determinants which affect customer satisfaction in the specified sector

Stage 3: Develop a parameter corresponding table for the specified sector

Stage 4: Generate the feasible solutions through the TRIZ contradiction matrix

Stage 5: Implement the feasible solutions

Stage 6: Are the results effective? If yes, go to stage 7; otherwase, go to stage 4.

Stage 7: Identify the next problem need to be resolved.

Stage 8: Is the new problem belonged to the same sector? If yes, back to stage 4; otherwise, return to stage 1.

Su et.al.(2008) recommended further studying for the explanation of the 39 TRIZ engineering parametersin order to enlarge the TRIZ based applications.

The aim of this study is to develop a methodology for health-care service sector by adapting the SERVQUAL scale parameters to TRIZ in the light of the study by Su et al. (2008) in order to improve service quality. The stages in the following section carried out to accomplish this aim. 
3. ADAPTING SERVQUAL SCALE TO TRIZ USING THE METHODOLOGY BY SU ET AL. (2008)

Stage 1: Defining the scope of the problem, and identifying the service sector under which it is classified

Improving the quality of hospital service is the problem, and it was categorized under the healthcare service sector.

Stage 2: Extracting the determinants that affect customer satisfaction of the health-care service sector

The determinants of service quality, namely SERVQUAL scale, were set as seen in Table 2 by Parasuraman et al. (1985). Studies show that the SERVQUAL scale is an effective indicator for the quality of health-care service (Çaha, 2007; Zaim et. al., 2009;
Vandamme and Leunis, 1993; Babakus and Mangold, 1992; Lee, 2005; Lam, 1997). Consequently, the determinants for health-care service sector were extracted as Table 2.

Stage 3: Developing a parameter-corresponding table for the hospital service sector

Health care service quality parameters and TRIZ engineering parameters were analogically evaluated, in this step. Firstly, we reviewed the implementation of $39 \mathrm{TRIZ}$ engineering parameters and the 10 parameters of SERVQUAL scale in literature. Then, parallel statements were matched each other after some discussions. The result of the parameter corresponding table for health-care service sector is shown in Table 3.

Table 2: The Determinants of SERVQUAL Scale for Health-Care Service Sector.

\begin{tabular}{|c|c|c|}
\hline Category & Determinants & Interpretations \\
\hline 1 & Access & $\begin{array}{l}\text { The accessibility to hospital from outside and the ease of access to materials in } \\
\text { hospital such as tools and electronic devices. }\end{array}$ \\
\hline 2 & Competence & To have the necessary knowledge and skills to provide services in hospital. \\
\hline 3 & Communication & $\begin{array}{l}\text { An effective communication with patients. A patient should understand the } \\
\text { language which is spoken by health workers and they should listen to the } \\
\text { patients. }\end{array}$ \\
\hline 4 & Courtesy & $\begin{array}{l}\text { To be regard, understanding, polish and friendly to patients. The behavior of } \\
\text { employees and nurses' should be very polite against patients during admissions } \\
\text { and housekeeping procedure. }\end{array}$ \\
\hline 5 & Credibility & $\begin{array}{l}\text { Employees should be trusted for patient. Patients should be sure that nurses are } \\
\text { well-informed. Patients should be able to feel safe that all of the employees are } \\
\text { trusted about every topic. }\end{array}$ \\
\hline 6 & Reliability & $\begin{array}{l}\text { When promises to do something, it does so. Keeping accurate records. } \\
\text { Employees should timely provide the services }\end{array}$ \\
\hline 7 & Responsiveness & Needed service should answer timely. Responding in time \\
\hline 8 & Security & To avoid the dangers and risks, to provide safety guarantees. \\
\hline 9 & $\begin{array}{l}\text { Understanding } \\
\text { the Customer }\end{array}$ & To understand the needs of patients and to know their needs. \\
\hline 10 & Tangibles & $\begin{array}{l}\text { Used equipment, communication materials, the physical appearance of } \\
\text { personnel and services provided in hospital should be very good. }\end{array}$ \\
\hline
\end{tabular}

Table 3: The Parameters Corresponding Table for Health-Care Service Sector.

\begin{tabular}{|c|l|c|l|}
\hline Category & $\begin{array}{l}\text { Determinants of } \\
\text { SERVQUAL Scale }\end{array}$ & $\begin{array}{l}\text { Parameter } \\
\text { Number }\end{array}$ & Parameter Name in TRIZ \\
\hline $\mathbf{1}$ & Access & $\mathbf{3 2}$ & Easy of Manufacture \\
\hline $\mathbf{2}$ & Competence & $\mathbf{2 9}$ & Manufacturing Precision \\
\hline $\mathbf{3}$ & Communication & $\mathbf{2 8}$ & Measurement Accuracy \\
\hline $\mathbf{4}$ & Courtesy & $\mathbf{3 4}$ & Easy of Repair \\
\hline $\mathbf{5}$ & Credibility & $\mathbf{1 3}$ & Stability of the Object's Composition \\
\hline $\mathbf{6}$ & Reliability & $\mathbf{2 7}$ & Reliability \\
\hline $\mathbf{7}$ & Responsiveness & $\mathbf{9}$ & Speed \\
\hline $\mathbf{8}$ & Security & $\mathbf{3 0}$ & External Harm Effects the Object \\
\hline $\mathbf{9}$ & $\begin{array}{l}\text { Understanding the } \\
\text { Customer }\end{array}$ & $\mathbf{2 8}$ & Measurement Accuracy \\
\hline $\mathbf{1 0}$ & Tangibles & $\mathbf{1 2}$ & Shape \\
\hline
\end{tabular}

Su et.al (2008) conducted their study by asking seven experts. However, we designed a survey form, and ten physicians (three of them has a title of Prof. Dr. and the rest of them is regular doctors) in the Ataturk University Hospital in Turkey were asked to answer the survey after creating the parameter corresponding table. At the beginning of the application of the survey, we clarified the definitions and the reasons related to mappings the parameters in each pair and corresponding TRIZ parameters for physicians. Each physician specified his/her opinion by choosing 'Agree' or 'Disagree' for each parameter in the survey. The results are shown in Table 4. 
Table 4: The Results of the Questionnaires From Physicians (A:Agree, D: Disagree).

\begin{tabular}{|c|c|c|c|c|c|c|c|c|c|c|c|c|c|c|c|c|c|c|c|c|c|c|c|c|}
\hline \multirow[b]{2}{*}{\begin{tabular}{|c}
$\begin{array}{c}\text { Determinants of } \\
\text { SERVQUAL } \\
\text { scale }\end{array}$ \\
\end{tabular}} & \multirow[b]{2}{*}{$\begin{array}{c}\text { Parameter name in } \\
\text { TRIZ }\end{array}$} & \multirow[b]{2}{*}{ No } & \multicolumn{2}{|c|}{\begin{tabular}{|l} 
Regular \\
Doctor \\
1
\end{tabular}} & \multicolumn{2}{|c|}{\begin{tabular}{|l|l|} 
Regular \\
Doctor \\
2
\end{tabular}} & \multicolumn{2}{|c|}{\begin{tabular}{|l} 
Regular \\
Doctor \\
3
\end{tabular}} & \multicolumn{2}{|c|}{ 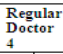 } & \multicolumn{2}{|c|}{\begin{tabular}{|l}
$\begin{array}{l}\text { Regular } \\
\text { Doctor } \\
5\end{array}$ \\
\end{tabular}} & \multicolumn{2}{|c|}{$\begin{array}{l}\begin{array}{l}\text { Regular } \\
\text { Doctor } \\
6\end{array} \\
\end{array}$} & \multicolumn{2}{|c|}{\begin{tabular}{|l} 
Regular \\
Doctor \\
7
\end{tabular}} & \multicolumn{2}{|c|}{\begin{tabular}{|l} 
Regular \\
Doctor \\
S
\end{tabular}} & \multicolumn{2}{|c|}{\begin{tabular}{|l|}
$\begin{array}{l}\text { Regular } \\
\text { Doctor } \\
9\end{array}$ \\
\end{tabular}} & \multicolumn{2}{|c|}{$\begin{array}{l}\begin{array}{l}\text { Regular } \\
\text { Docttor } \\
10\end{array} \\
\end{array}$} & \multicolumn{2}{|c|}{\begin{tabular}{|l} 
Final \\
Results
\end{tabular}} \\
\hline & & & $A$ & D & $\mathbf{A}$ & D & A & D & $A$ & $\mathbf{D}$ & $A$ & $\mathbf{D}$ & A & $\mathbf{D}$ & A & $\mathbf{D}$ & $\mathbf{A}$ & $\mathbf{D}$ & $A$ & $\mathbf{D}$ & $\mathbf{A}$ & $\mathbf{D}$ & $\mathbf{A}$ & D \\
\hline Access & Easy of manufacture & 32 & + & & + & & + & & + & & + & & + & & + & & + & & + & & + & & + & \\
\hline Competence & $\begin{array}{l}\text { Manufacturing } \\
\text { precision }\end{array}$ & 29 & + & & + & & + & & + & & + & & + & & + & & + & & + & & + & & + & \\
\hline Communication & $\begin{array}{l}\text { Measurement } \\
\text { accuracy }\end{array}$ & 28 & & + & + & & + & & + & & + & & & + & & + & & + & & + & & + & & + \\
\hline Courtesy & Easy of repair & 34 & + & & + & & + & & + & & + & & & + & & + & + & & & + & + & & + & \\
\hline Credibility & $\begin{array}{c}\text { Stability of the } \\
\text { object's composition }\end{array}$ & 13 & + & & + & & + & & + & & + & & + & & & + & & + & + & & + & & + & \\
\hline Reliability & Reliability & 27 & + & & + & & + & & + & & + & & + & & + & & + & & + & & & + & + & \\
\hline Responsiveness & Speed & 9 & + & & + & & + & & + & & + & & + & & + & & + & & + & & + & & + & \\
\hline Security & $\begin{array}{l}\text { Extemal harm } \\
\text { effects the object }\end{array}$ & 30 & + & & + & & + & & + & & + & & & + & + & & + & & + & & + & & + & \\
\hline $\begin{array}{l}\text { Understanding } \\
\text { the Customer }\end{array}$ & $\begin{array}{l}\text { Measurement } \\
\text { accuracy }\end{array}$ & 28 & & + & & + & + & & + & & + & & + & & & + & & + & & + & & + & & + \\
\hline Tangibles & Shape & 12 & + & & + & & + & & + & & + & & + & & + & & + & & & + & + & & + & \\
\hline
\end{tabular}

After putting 10 pairs of analogical mapping parameters together, we came up with two mapping pair, 'Communication vs. Measurement accuracy' and 'Understanding the Customer vs. Measurement accuracy' which only four physicians (less than 50\%) agreed with, while the rest of the pairs were approved by more than $50 \%$ of physicians. Therefore, we conclude that 8 pairs of parameter-corresponding results are analogically related. In order to prove the harmony of the physicians' opinions, the survey results were evaluated statistically. Following statements were hypothesized:

$\mathbf{H}_{\mathbf{0}}$ : There are no differences among physicians' opinions.

$\mathbf{H}_{1}$ : There is a difference among physicians' opinions on the effectiveness of the parameter mapping results.

$$
T=c x(c-1) x \frac{\sum_{j=1}^{c}\left(C_{j}-\frac{N}{c}\right)^{2}}{\sum_{i=1}^{r} R_{i}\left(c-R_{i}\right)}=10 x(10-1) x \frac{\sum_{j=1}^{10}\left(C_{j}-\frac{72}{10}\right)^{2}}{\sum_{i=1}^{r} R_{i}\left(10-R_{i}\right)}=10 \times 9 x \frac{7.6}{64}=10.688
$$

be rejected. It means that there is no statistically significant difference among the physicians' opinions. As a result, the parameter corresponding table was formed with 8 pairs of mapped parameters.

To ensure the customer satisfaction in hospitals, the determinants of health-care service sector should be improved. However, improving one parameter may worsen another one. In this situation the problem is named as an inventive problem. Classic TRIZ method presents a problem solution set with 40 TRIZ inventive principles in a 39x39 contradiction matrix for inventive problems. The original contra-
Like Su et.al.(2008), Cochran test was used in the statistical analysis since the response variables of the survey are binary as "agree" and "disagree". For the calculation of the test statistics, agreement and disagreement in the survey were coded as " 1 " and " 0 ", respectively. Then the results were arranged with " $c$ " columns and " $r$ " rows representing the physicians and the determinants, respectively. In the Cochran formula the number of physicians (c), the column total for the $j^{\text {th }}$ treatment $(\mathrm{Cj})$, the number of blocks $(\mathrm{r})$, the row total for the $i^{\text {th }}$ block (Ri), and the grand total $(\mathrm{N})$ were used. Calculation was shown in equation (1).

The critical statistic value for 0.05 (a) significance level and nine degrees of freedom is 16.919. As the test statistic (10.688) was lower than the critical region value (16.919), the null hypothesis $\left(H_{0}\right)$ cannot

diction matrix was extracted for our 8 determinants, and problem solution set was taken from the intersections for all possible contradictions resulting in a new $8 \times 8$ contradiction matrix for health-care service quality problems (Table 5 ). The numbers in the intersection areas of Table 5 indicate the original 40 TRIZ problem solution principles.

After this stage, inventive solutions can be searched for the quality problems in health-care service sector using this new contradiction matrix (Table 5) employing the methodology given in Figure 1. Remaining steps, proposed by Su et.al.(2008) do not 
Table 5:The Extracted Contradiction Matrix for Health-Care Service Sector.

\begin{tabular}{|c|c|c|c|c|c|c|c|c|c|}
\hline & \multicolumn{8}{|c|}{ Worsening Parameters } \\
\hline & & 1 & 2 & 3 & 4 & 5 & 6 & 7 & 8 \\
\hline & $\begin{array}{l}\text { Improving } \\
\text { Parameters }\end{array}$ & Access & Competence & Courteșy & Credibility & Reliability & Responsiveness & Security & Tangibles \\
\hline 1 & Access & $\cdots$ & $\cdots$ & $(35.01-11-09)$ & $(11-13-01)$ & $\cdots$ & $(35-13.08-01)$ & $(24-02)$ & $(01.28-13.27)$ \\
\hline 2 & Competence & $\cdots$ & $\ldots$ & $(25-10)$ & $(30-18)$ & $(11-32-01)$ & $(10-28-32)$ & $(26-28-10-36)$ & $(32-30-40)$ \\
\hline 3 & Courtesy & $(01-35-11-10)$ & $(25-10)$ & $\ldots$ & $(02-35)$ & $(11-10-01-16)$ & $(34.09)$ & $(35 \cdot 10 \cdot 02 \cdot 16)$ & $(01-13 \cdot 02 \cdot 04)$ \\
\hline 4 & Credibility & $(35.19)$ & 18 & $(02-35-10-16)$ & $\ldots$ & $\ldots$ & $(33-15 \cdot 28-18)$ & $(35 \cdot 24-18-30)$ & $(22.01 \cdot 18.04)$ \\
\hline 5 & Reliability & $\ldots$ & $(11-32.01)$ & $(01-11)$ & $\ldots$ & $\ldots$ & $(21 \cdot 35 \cdot 11 \cdot 28)$ & $(27 \cdot 35 \cdot 02.40)$ & $(35 \cdot 01 \cdot 16 \cdot 11)$ \\
\hline 6 & Responsiveness & $(35-13 \cdot 08-01)$ & $(10-28-32-35)$ & $(34-02-28-27)$ & $(28-33-01-18)$ & $(11 \cdot 35 \cdot 27 \cdot 28)$ & $\ldots$ & $(01 \cdot 28-35 \cdot 23)$ & $(35 \cdot 15 \cdot 18 \cdot 34)$ \\
\hline 7 & Security & $(24.35 .02)$ & $(26 \cdot 28 \cdot 10 \cdot 18)$ & $(35-10-02)$ & $(35 \cdot 24 \cdot 30 \cdot 18)$ & $(27 \cdot 24 \cdot 02 \cdot 40)$ & $(21 \cdot 22 \cdot 35 \cdot 28)$ & $\cdots$ & $(22.01 \cdot 03 \cdot 35)$ \\
\hline 8 & Tangibles & $(01-32-17-28)$ & $(32-30 \cdot 40)$ & $(02 \cdot 13.01)$ & $(33 \cdot 01 \cdot 18 \cdot 04)$ & $(10-40-16)$ & $(35 \cdot 15 \cdot 34 \cdot 18)$ & $(22.01 \cdot 02.35)$ & $\ldots$ \\
\hline
\end{tabular}

conducted in here due to the fact that the following case study gives all steps given in figure 1 . The following imaginary case study was carried out to examine the effectiveness of the methodology and the extracted contradiction matrix for health-care services.

\section{CASE STUDY}

A case study was conducted to explore all steps of the proposed innovative approach which their steps are given in figure 1. The goal of this case study is to improve the service quality in an intensive care

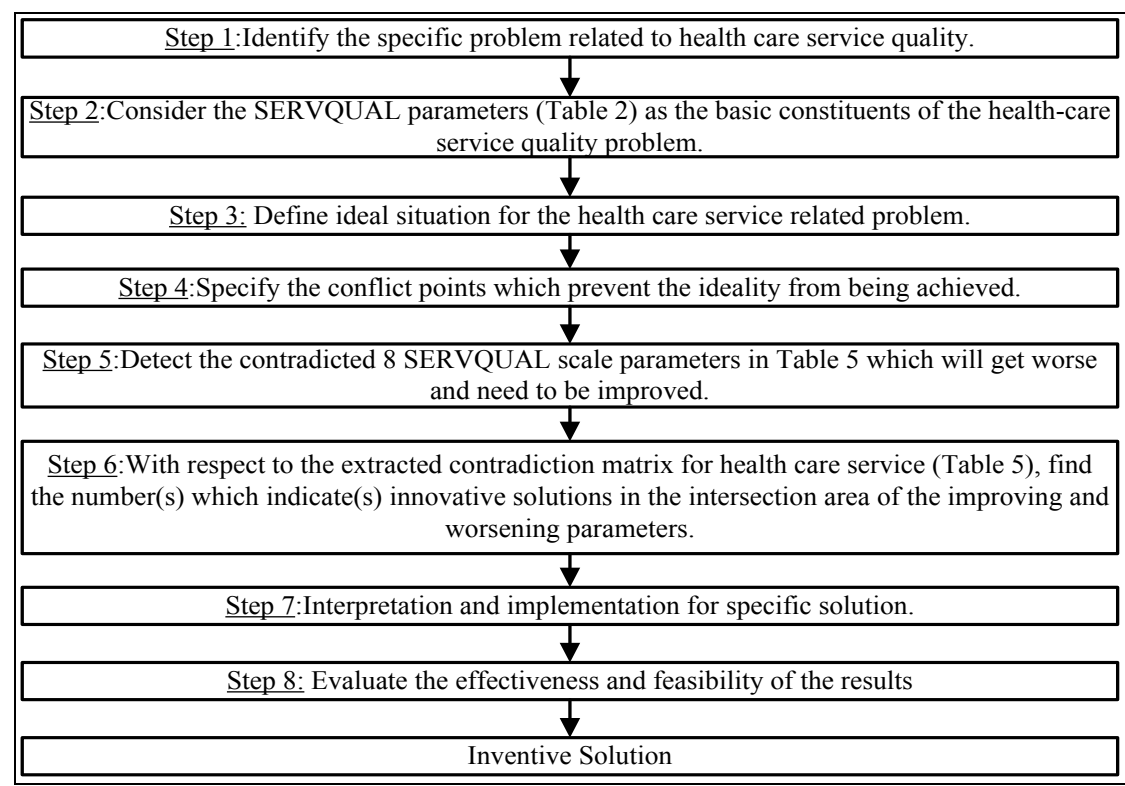

Figure 1: The Systematic TRIZ Based Problem-Solving Process for Health-Care Service Quality Problems.

unit (ICU). All of the steps of the proposed innovative approach and regarding solution explanations are given step by step in the following.

Step1: Identify the specific problem related to health care service quality.

Intensive care units (ICUs) can be considered as one of the most important department in hospital.
As indicated on line website at https://www.ecri. org, there is four million U.S. patients treated in ICUs each year and also nearly all of them suffer potentially from harmful events. Therefore, the employees in ICU should notice any changes in the situation of patients and act rapidly but carefully. In addition to this, they need more time to ensure patient safety by reducing mistakes. 
Step 2: Consider the SERVQUAL parameters (see Table 2) as the basic constituents of the health-care service quality problem.

We took into account the SERVQUAL scale parameters as the determinants of hospital service quality given in Table 2 .

Step 3: Define ideal situation for the health care service related problem.

In this problem, we defined ideal situation for the specified problem as 'the development of action at the right time without any error or side effect.

Step 4: Specify the conflict points which prevent the ideality from being achieved.

Responsiveness is an important service quality parameter in ICU due to the critical situation of the patients. Increasing the speed of action by employees enhances "responsiveness", but also increases errors or side effects causing patient safety problems.

Step 5: Detect the contradicted 8 SERVQUAL scale parameters in Table 5 which will get worse and need to be improved.

In this case study, contradiction is between "Responsiveness" and "Security". Therefore, our improving and worsening features are "Responsiveness" and "Security", respectively.

Step 6: With respect to the extracted contradiction matrix for health care service (see Table 5), find the number(s) which indicate(s) innovative solutions in the intersection area of the improving and worsening parameters.

Found numbers in the intersection area of "Responsiveness" which is improving parameter and "Security" which is worsening parameter are 1 (Segmentation), 23(Feedback), 28(Mechanics substitution) and 35(Parameters and properties changes). One appropriate solution can be enough to overcome conflict situation handed in this paper. Nevertheless, we interpreted all of the proposed inventive solutions from contradiction matrix except inventive principle of 35(Parameters and properties changes).

Step 7: Interpretation and implementation for specific solution.

The following approaches are related to the solution principles. Details on explanation of inventive solutions can be found in (Rantanen and Domb, 2008; Chai et.al., 2005). Obtained inventive solutions from extracted contradiction matrix for hospital service quality are explained in the following.
Take inventive principle 1 (Segmentation):

Responsiveness (responding in time) can be improved, if we separate patients who came to ICU from other patients, families and unrelated personal. Health personnel such as doctors and nurses are provided with accessing and interfering with patents. Dr.Pande R., who is a chairman of department of Critical care and Emergency Medicine BLK Memorial Hospital, suggests that a direct elevator can be used to transfer sick patients to and fro from the ICU, reducing transport time and avoiding the visitors.

Take inventive principle 23 (feedback):

Chai et. al. (2005) explained this parameter to resolve service contradictions as "introduce feedback (referring back, cross-checking) to improve a process or action" and "If feedback is already used, change its magnitude or influence".

Teamwork can improve responsiveness. It helps to decrease mistake by each people in team monitoring each other. Occurred errors can be corrected timely and returns to correct errors will not be done again and again. Therefore, responsiveness can be improved without losing security.

Take inventive principle 28 (Replace mechanical means with sensory):

Med (1995) claim that access to the room in emergency situations increase, if sliding glass doors, which work with sensory, are used. This improves the speed of action (responsiveness) by employees without decreasing security.

Step 8: Evaluate the effectiveness and feasibility of the results

As can be seen above explained inventive solutions, the proposed approach provides the effectiveness and feasibility of the output solutions and also the developed methodology.

\section{CONCLUSION}

This study has proposed a new innovative approach based on TRIZ methodology and SERVQUAL scale. The aim of proposed approach is to solve problems and to improve the quality of health-care service. We combined TRIZ methodology and SERVQUAL scale. Because SERVQUAL is a well known scale to measure hospital service quality. In addition to this, TRIZ is also very useful to solve problems innovatively. Therefore, we mapped the determinants of SERVQUAL scale with the analogical explanations of the 39 TRIZ engineering parameters. A questionnaire has been applied to ten doctors (three of them 
are Professors (academic) and the rest of them are regular doctors) in the Ataturk University Hospital in Turkey for confirming our study. Then, a case study is conducted to show that how we can apply this new innovative approach to health-care service. The results are impressing for TRIZ' future. However, future work is needed to validate and reliability of the proposed approach. The proposed approach pro- vides an alternative solution to improve the quality of health-care service easily with promising future with future study. We expand the applicability of the TRIZ contradiction matrix thanks to this study. For future research, solution options in the extracted contradiction matrix for hospital service sector may be explained clearly. Proposed approach can be applied to real life problems.

\section{REFERENCES}

Akay, D., Demiray, A., and Kurt, M.(2008) "Collaborative Tool for Solving Human Factors Problems in the Manufacturing Environment: The Theory of Inventive Problem Solving Technique (TRIZ) Method" International Journal of Production Research, 46(11):2913-2925.

Andrews, L.B., Stocking, C., Krizek, T., Gottlieb, L., Krizek C., Vargish, T., and Siegler, M. (1997) "An Alternative Strategy for Studying Adverse Events in Medical Care" Lancet, 349:309-313.

Asubonteng, P., McCleary, K.J., and Swan. J.E. (1996) "SERVQUAL Revisited: A Critical Review of Service Quality” Journal of Services Marketing, 10(6):62-81.

Babakus, E., and Mangold W.G. (1992) "Adapting the Servqual Scale to Hospital Services: An Empirical Investigation" Health Services Research, 26(6):76-786.

Bariani, P.F, Berti G.A., and Lucchetta G. (2004) "A Combined DFMA and TRIZ Approach to the Simplification of Product Structure" Proceedings of the Institution of Mechanical Engineers, Part B: Journal of Engineering Manufacture, 218:1023- 1027.

Buttle, F.(1996) "SERVQUAL: Review. Critique, Research Agenda" European Journal of Marketing, 30(1):832.

Cemgil, S. (2006) "Theory of Inventive Problem Solving (TRIZ) in Forming and Developing Education Standards" Master Thesis, İzmir, Dokuz Eylül University.

Chai, C.H., Zhang, J., and Tan K.C. (2005) "A TRIZ-Based Method for New Service Design" Journal of Service Research 8(1):48-66.

Chen, C.K., Shie, A.J., Wang, K.M. and Yu,C.H. (2010) "Developing A TRIZ-Based Service System Innovation Model for Aging in Place" The 11th Asia Pacific Industrial Engineering and Management Systems Conference, 1-9.

Cool, J.P. (2005) "Marketing Triz in the Global Marketplace: A Primer" Proceeding in TRIZCON2005, Brighton, MI USA.
Coulthard, L. J. M. (2004) "Measuring Service Quality: A Review and Critique of Research Using SERVQUAL" International Journal of Market Research, 46(4):479-497.

Cullen, D.J., Sweitzer, B.J., Bates, D.W., Burdick, E., Edmondson, A. and Leape, L.L. (1997) "Preventable Adverse Drug Events In Hospitalized Patients: A Comparative Study of Intensive Care And General Care Units" Critical Care Medicine, 25:1289-1297.

Çaha, H. (2007) "Service Quality in Private Hospitals in Turkey" Journal of Economic and Social Research, 9(1):55-69.

DeLeval, M.R., Carthey, J., Wright, D.J., Farewell V.T. and Reason, J.T. (2000) "Human Factors and Cardiac Surgery: A Multicenter Study" Journal of Thoracic and Cardiovascular Surgery, 119:661-72.

Domb, E. (2003) "TRIZ For Non-Technical Problem Solving" Keynote Address at the 3d European TRIZ Congress, Zurich, Switzerland.

Dourson, S. (2004) "The 40 Inventive Principles of TRIZ Applied to Finance" The TRIZ Journal, 1:1-23.

ECRI Institute, (2011) https://www.ecri.org/Products/Pages/Critical_Care_Guide.aspx

Elizabeth, A. A. (1995) "Measuring Service Quality at A University Health Clinic" International Journal of Health Care Quality Assurance, 8(2):32-37.

Ersin, F. (2009) "Implementation of TRIZ Methodology in Human Capital” Master Thesis, İstanbul, Bahcesehir University.

Express Healthcare, (2011) http://www.expresshealthcare.in/201001/criticare02.shtml

Gronroos, C.(1984) "A Service Quality Model and Its Marketing Implications" European Journal of Marketing, 18(4):36-44.

Gilmore, A. and McMullan, R. (2009) "Scales in Services Marketing Research: A Critique And Way Forward" European Journal of Marketing, 43(5/6):640-651. 
Hipple, J. (2005a) "The Integration of TRIZ With Other Ideation Tools And Processes As Well As With Psychological Assessment Tools" Creativity and Innovation Management, 14(1):22-33.

Hipple, J.(2005b) "The Integration and Strategic Use of TRIZ with the Creative Problem Solving Process" $1-7$.

Ilevbare, I., Phaal, R., Probert, D. and Padilla, A.T. (2011) "Integration of TRIZ and Roadmapping for Innovation, Strategy, and Problem Solving. Phase 1 TRIZ, Roadmapping and Proposed Integrations" Centre for Technology Management, UK, University of Cambridge.

Ladhari, R. (2008) "Alternative Measures of Service Quality: A Review" Managing Service Quality, 18(1):65-86.

Ladhari, R. (2009) "A Review of Twenty Years of SERVQUAL Research" International Journal of Quality and Service Sciences, 1(2):172-198.

Lam, S.S.K. (1997) "SERVQUAL:A Tool for Measuring Patients' Opinions of Hospital Service Quality In Hong Kong” Total Quality Management, 8(4):145-152.

Lee, J. (2005) "Measuring Service Quality in A Medical Setting in A Developing Country: The Applicability Of SERVQUAL"Services Marketing Quarterly, 27(2):1-14.

Leonard, M., Graham, S.,and Bonacum, D. (2004) "The Human Factor: The Critical Importance of Effective Teamwork and Communication in Providing Safe Care" Quality and Safety in Health Care, 13, i84-i90.

Lin, C.S. and Su, C.T. (2007) "An Innovative Way to Create New Services: Applying the TRIZ Methodology" Journal of the Chinese Institute of Industrial Engineers, 24(2):142-152.

Marsh, D.G., Waters,F.H. and Marsh, T.D. (2004) "40 inventive Principles with Applications in Education" The TRIZ Journal, 1-17.

Movarrei, R. and Vessal, S.R. (2006) "Application of Theory of Inventive Problem Solving in Customer Relationship Management" Management of Innovation and Technology, 2006 IEEE International Conference, 2123 June, Singapore, China.
Movarrei, R.and Vessal, S.R. (2007) "Theory of Inventive Problem Solving (TRIZ) Applied in Supply Chain Management of Petrochemical Projects" Industrial Engineering and Engineering Management 2007 IEEE International Conference, 2-4 December, Singapore, China.

Orloff, M.A. (2006) Inventive Thinking Through TRIZ: A Practical Guide 2nd Edition, New York, Springer.

Parasuraman, A., Berry, L.L., and Zeithaml, V.A. (1985) "A Conceptual Model of Service Quality and Its Implications for Future Research" Journal of Marketing, 49(4):41-50.

Parasuraman, A., Zeithaml, V.A., and Berry, L.L. (1988) "SERVQUAL: A Multiple-Item Scale For Measuring Consumer Perception of Service Quality" Journal of Retailing, 64(1): 12-40.

Parasuraman, A., Zeithaml, V.A., and Berry, L.L. (1991) "Refinement and Reassessment of the SERVQUAL Scale" Journal of Retailing, 67(4):420-450.

Parasuraman, A., Zeithaml, V.A., and Berry, L.L. (1994) "Reassesment of Expectations As A Comparison Standard in Measuring Service Quality: Implications for Further Research” Journal of Marketing, 56:111-124.

Petrali, P. (2004) "Integrating TRIZ and Other Methodologies in Product/Process Re-Engineering" The TRIZ Journal,1-6.

Pin, S.C., Haron, F., Sarmady, S., Talib, A.Z., and Khader, A.T. (2011) "Applying TRIZ Principles In Crowd Management” Safety Science, 49(2):286-291.

Retseptor, G. (2003) “40 Inventive Principles in Quality Management" The TRIZ Journal, 1-25.

Retseptor, G. (2005) "40 inventive principles in marketing, sales and advertising”, The TRIZ Journal, 1-16.

Rantanen, K. and Domb, E. (2008) Simplified TRIZ: New Problem Solving Applications for Engineers and Manufacturing Professionals, Second Edition, Auerbach Publication.

Sakao, D. (2007) "A QFD-Centred Design Methodology for Environmentally Conscious Product Design" International Journal of Production Research, 45(1819):4143-4162.

Savransky, S.D. (2000) Engineering of Creativity:Introduction to Triz Methodology Of Inventive Problem Solving, 1th Edition, New York, CRC Press.

Shahin, A. and Pourhamidi, M. (2011) "Service TRIZ: An Approach For Service Quality Design - With A Case Study in The Hospitality Industry" International Journal of Business Innovation and Research, 5(4):291-308. 
Shirwaiker, R.A. and Okudan, G.E. (2008) "Triz and Axiomatic Design: A Review of Case-Studies and A Proposed Synergistic Use" Journal of Intelligent Manufacturing, 19(1):33-47.

Silverstein, D., DeCarlo, N. and Slocum, M. (2008) Insourcing Innovation How to Achieve Competitive Excellence Using TRIZ, 1 th Edition, USA, Taylor \& Francis.

$\mathrm{Su}$, C.T., and Lin, C.S. (2008) "A Case Study on The Application of Fuzzy QFD in TRIZ for Service Quality Improvement” Quality \& Quantity, 42(5):563-578.

Su, C.T., Lin, C.S. and Chiang, T.L. (2008) "Systematic Improvement in Service Quality Through TRIZ Methodology: An Exploratory Study" Total Quality Management \& Business Excellence, 19(3):223-243.

James, C. (1990) "Consumer Perceptions of Service Quality: An Assestment of SERVQUAL Dimensions" Journal of Retailing, 66(1):33-55.

Jiang, J.C., Sun, P. and Shie,A.J.(2011) "Six Cognitive Gaps by Using TRIZ and Tools for Service System Design" Expert Systems with Applications, 38(12):1475114759.

Tong, L.H., Cong H., and Lixiang, S. (2006) "Automatic Classification of Patent Documents for TRIZ Users" World Patent Information, 28(1):6-13.

Tony, C.and Stephen, W. (1997) "The Role of Expectations in the Perception of Health Care Quality: Developing A Conceptual Model" International Journal of Health Care Quality, 10(3):131-140.

Tsai, C.C., Chang, C.Y. and Tseng C.H. (2004) "Optimal Design of Metal Seated Ball Valve Mechanism" Structural and Multidisciplinary Optimization, 26(3-4):249-255.

Vandamme, R., and Leunis, J. (1993) "Development of A Multiple-Item Scale for Measuring Hospital Service Quality" International Journal of Service Industry Management, 4(3):30-49.
Vande Voorde, K.M., and France, A.C. (2002) "Proactive Error Prevention In The Intensive Care Unit" Critical Care Nursing Clinics of North America 14(4):347358.

Wang, F.K. and Chen, K.S. (2010) "Applying Lean Six Sigma and Triz Methodology in Banking Services" Total Quality Management, 21(3):301-315.

Wei, Y., Qingming, W., Yongqiang, C. and Huadong, Z. (2006) "Research on Inventive Problem Solving Process Model Based on AHP/TRIZ" International Technology and Innovation Conference, 2285-2290.

Yamashına, H., Ito T. and Kawada H. (2002) "Innovative Product Development Process by Integrating QFD and TRIZ" International Journal of Production Research, 40(5):1031-1050.

Zaim, H., Bayyurt, N. and Zaim, S. (2009) "Service Quality and Determinants of Customer Satisfaction in Hospitals: Turkish Experience" EABR \& TLC Conference Proceedings, 1-7.

Zhang, J., Chai, K., and Tan, K. (2003) "40 Inventive Principles with Applications in Service Operations Management" The TRIZ Journal, 1-16.

Zhang, J., Chai K.H. and Tan K.C. (2005)" Applying TRIZ to Service Conceptual Design: An Exploratory Study" Creativity annd Innovation Management, 14(1):34-42.

Zlotin, B., Zusman, A., Kaplan, L., Vinepolschi, S., Proseanic, V. and Malkin, S. (2005) TRIZ Beyond Technology: The Theory And Practice of Applying TRIZ to NonTechnical Areas Detroit, Ideation International Inc.

Zouaoua, D., Crubleau, P., Mathieu, J., Thieblemont, R. and Richir, S. (2010) "TRIZ and The Difficulties in Marketing Management Applications" Technology Management for Global Economic Growth (PICMET), 1-10. 